\title{
Improving the Efficiency of a Mining Enterprise by Coordinating Production Processes
}

\author{
Alexey Tyurin ${ }^{1, *}$, and Ildar Kuvataev ${ }^{2}$ \\ ${ }^{1}$ T.F. Gorbachev Kuzbass State Technical University, Department of Automobile Transportation, \\ 650000 Kemerovo, 28 Vesennya st., Russian Federation \\ ${ }^{2}$ Kazakh Humanitarian Juridical Innovative University, EKR, Semey, 11Mangilik st., Republic of \\ Kazakstan
}

\begin{abstract}
To improve the efficiency of the mining industry, it is necessary to coordinate all production processes, which allows reducing unproductive downtime of mining and transport equipment, increasing their productivity, and reducing the cost of operations at all stages of the production cycle. To achieve this result, the article uses a systematic approach to consider the features of planning the work of all departments of the coal mine, starting with drilling and blasting operations on the sites and ending with the shipment of finished products to consumers. Based on the example of JSC "Chernigovets" in the Kemerovo region, the article considers a two-level model for planning the work of all divisions of the enterprise for a month, taking into account the dynamics of resource use of production and transport sections. Taking into account the uneven performance of production operations and the wide variety of mining equipment used at the stages of preparation, excavation, excavation, transportation, processing and shipment of finished products to external rail transport, it is possible to use a hierarchical two-level system with aggregation of processes at the first level and their detail at the second level. Using the dynamic programming method allowed us to solve the problem of planning the activities of all divisions of the enterprise at the first level and identify the boundaries of changes in the planned indicators at the second level, which do not worsen the results achieved at the first level. The proposed method of planning the operation of the mine will allow you to quickly track the achieved indicators, compare them with the planned ones and, if necessary, adjust the work of the enterprise's divisions in real time to achieve the best performance indicators of the coal mine as a whole.
\end{abstract}

\section{Introduction}

Applying a systematic approach to the consideration of all production processes of a mining enterprise allows you to link all these processes with each other, identify their mutual influence, and determine the order of interaction of performers to achieve the overall goal of the section.

The need to link strategic, tactical and operational decisions when operating open - pit mining enterprises was considered in $[1,2,3]$.

\footnotetext{
*Corresponding author: alexturin07@rambler.ru
} 
When planning the activities of a coal mine for a month, it is necessary to take into account the uneven flow of production and transport processes, which was noted in [4] and a logistics approach to managing these processes is proposed.

At the stages of mining and moving overburden rocks to dumps, powerful excavatorautomobile complexes operate, the activities of which are subject to many random factors that lead to rapid correction of the processes at these stages $[5,6,7]$. Various technological parameters of excavators and vehicles, such as bucket capacity, number of loading cycles, dump truck body capacity, loading intensity, and the intensity of arrival of vehicles at the loading site, affect the control system for the movement of rock mass between the cut objects $[8,9,10,11]$. The choice of the forms of regulation of flow processes of incision depends on the degree of coherence between the various production units with the use of information management systems all processes $[12,13,14,15,16]$.

The main flow processes at the coal mine include drilling and blasting, excavation and transportation of overburden, mining and transportation of coal to warehouses, processing at the factory, and shipment to consumers via the railway network of JSC "Russian Railways" (figure 1).

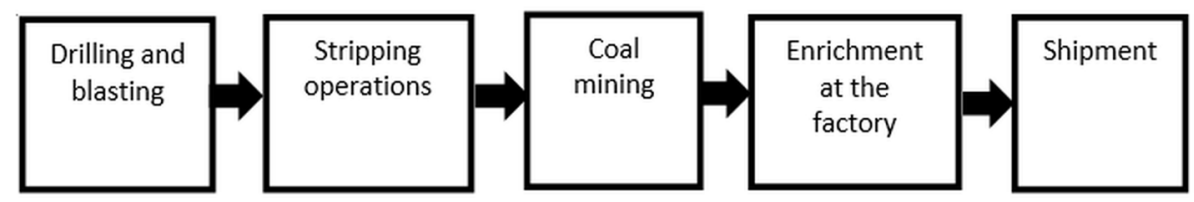

moving the material flow from process to process

Fig. 1. The main processes diagram of material flow movement.

Specifying the parameter all parts of the coal enterprise is, on the one hand, the demand for coal of a suitable type, on the other hand, the need to improve mining compliance with quality characteristics of the coal. Therefore, the level of demand affects the intensity of shipment (block 5), which, in turn, affects the concentrator operation mode (block 4). The need to maintain a certain productivity of the factory leads to the corresponding mode of coal delivery from intermediate warehouses (block 3 ). The intensity of coal removal from warehouses affects the speed of work on overburden sites (block 2), which, in turn, depends on the timeliness of drilling and blasting operations (block 1). Thus, all processes are interconnected and depend on each other.

To assess the efficiency of the coal mine as a whole, let's consider a two-level model, where the main processes are considered at the first level, and the work within these processes is detailed at the second level (figure 2).

Let's look at the methodology for planning work for a month in the first three main processes.

The monthly plan for stripping and mining operations determines the placement of each excavator along the ledges front (mining areas), the duration of the excavators ' work on each site, the volumes of mining (by mineral grades) and stripping operations performed by them. The plan is calculated based on geological, technological, organizational, and economic conditions.

In particular, the following conditions may be taken into account:

1. The ledges working platforms width on each section must be at least minimum.

2. To ensure that traffic on the ledges and placement of congresses the promotion of a certain portion of the lower ledge shall not exceed the advance connecting portion overlying the ledge. 


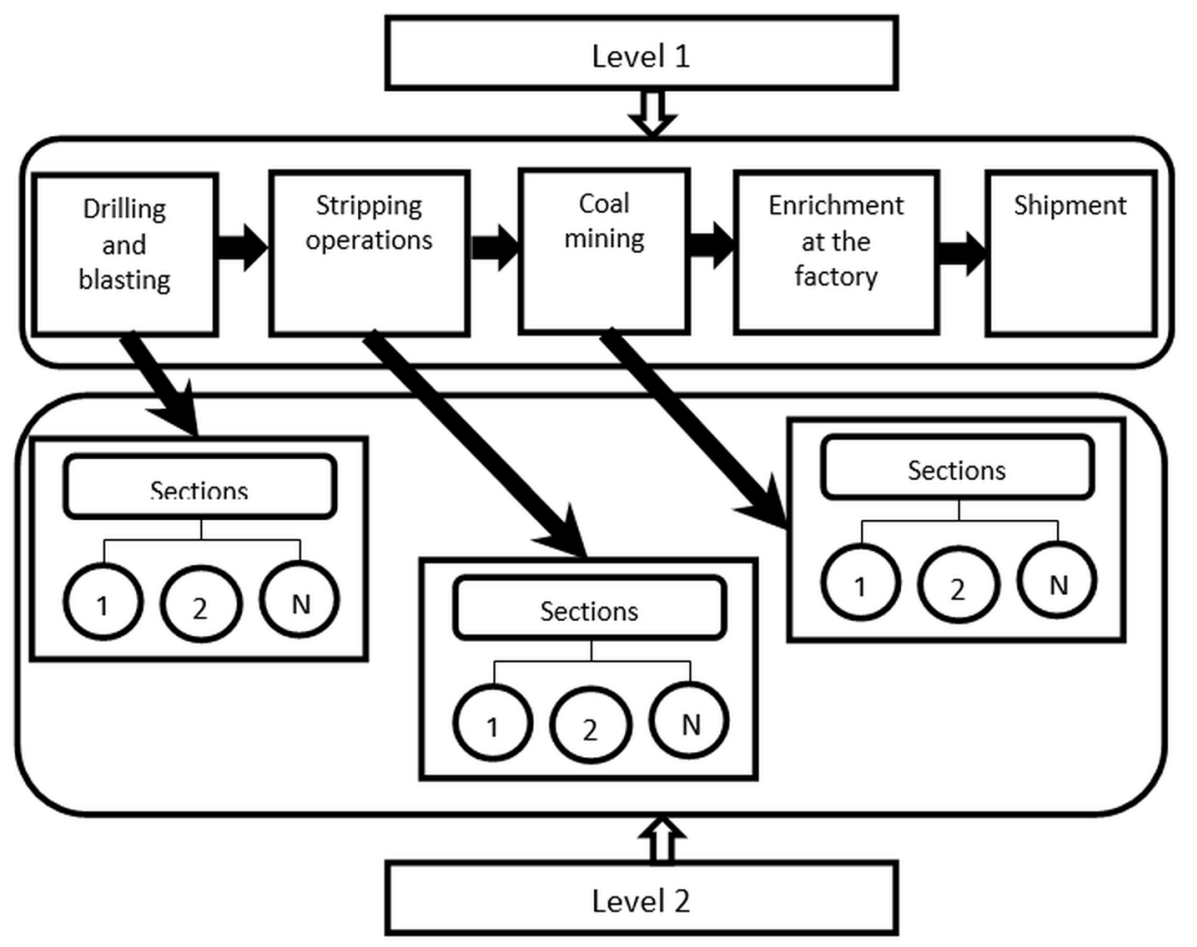

Fig. 2. Two-level process control system at a coal mine.

3. The movement of the front work ledge for the planning period is limited by the maximum possible speed of the advancing front or the position of the boundary pit to the upper horizons.

4. Compliance with the requirements for the extraction of rock mass of each type in the specified volumes and the quality of the extracted coal.

5. The volume of rock mass at each step of the front movement may consist of blasted rock and rock prepared for drilling.

6. The volume of each excavator work is determined taking into account its working time fund and operational productivity in specific mining conditions.

7. The total duration of each excavator operation on the ledge various sections should not exceed the planned time of its operation.

8. When determining the volume of excavation and loading operations on each horizon, the maximum possible volume of traffic that can be performed by the quarry transport for the planned period should be taken into account.

Monthly plan of blasting determines the location and size abusively blocks on every horizon, prepared by the ledges as the result of the hole drilling, the volume of rock mass, the volume of each drilling rig. The conditions for drawing up a drilling and blasting plan are:

1. The volume of rock mass prepared for drilling on the horizon by drilling rigs fixed to the ledge is determined by the productivity of the blasted rock and the desired operation duration of each machine.

2. The total operation time of each drilling rig on all sections is equal to the total planned time of its operation for a month.

3. Drilling sites on each ledge should be selected taking into account the preservation of the minimum width of the working platforms and the requirements for the development of the mining front of the ledges. 
4. Search for contours of drilling sites is performed within the specified borders.

\section{Materials and methods}

The object of research is JSC "Chernigovets". At the coal mine, drilling and blasting and stripping operations are carried out simultaneously on several sites for a month, after which the rock mass is delivered to four road and two railway dumps. Mining operations are also carried out on several sites, after which the coal is delivered by dump trucks to two coal warehouses, which are intermediate points for moving the material flow. Coal is transported by rail from coal warehouses to the processing plant. After enrichment of marketable coal shipped on rail and transported to the station "Miner" of JSC "Russian Railways".

Let's consider the mathematical formulation of the coal mine level 1 main processes controlling problem (figure 2). There are 5 main processes used at this level. We introduce the following notations: $x_{i}$ - the scope of work for the month on the process $i ; c_{i}-$ average cost of performing work in process $i$; $Q_{i}$ - planned monthly amount of work on process $i ; P_{i}$ - daily productivity of mining, transport and other equipment in process $i$; $T_{i}$ - the maximum allowed operating time of mining, transport and other equipment in the process $i$.

The target function is expressed as follows:

$$
\sum_{i=1}^{5} c_{i} x_{i} \rightarrow \min
$$

under constraints

$$
\begin{gathered}
x_{i} \geq Q_{i}, \quad i=1, \ldots, 5 \\
\frac{x_{i}}{P_{i}} \leq T_{i}, \quad i=1, \ldots, 5 \\
x_{i} \geq 0, \quad i=1, \ldots, 5
\end{gathered}
$$

Consider the mathematical formulation of the process control problem level 2 of the coal mine (figure 2). First, we will calculate the optimal values of drilling and blasting and Stripping operations. At the same time, during a month, work can be performed on 15 sites, which can be in the following States: 1 - drilling and blasting operations have been completed completely, the mining mass is being excavated and transported; 2 - the site is ready for drilling and blasting; 3 - drilling and Stripping operations can be performed on the site. The calculation will be based on state 3 .

To do this, enter the following notation: $x_{i}^{1}$ - the volume of drilling and blasting operations per month in section $i ; x_{i}^{2}$ - the volume of overburdening work per month on section $i$; $c_{i}^{1}$ - cost of performing drilling and blasting operations on section $i$; $c_{i}^{2}-$ cost of performing overburden work on section $i ; Q_{i}^{1}$ - planned monthly volume of drilling and blasting operations in section $i ; Q_{i}^{2}$ - planned monthly volume of overburden work 
on section $i ; P_{i}^{1}$ - daily productivity of drilling rigs in section $i ; P_{i}^{2}$ - daily productivity of excavators in section $i$; $T_{i}^{1}$ - the maximum time allowed for the work of drilling rigs on the section $i ; T_{i}^{2}$ - the maximum time allowed for the work of the excavators at the section $i$.

The target function is expressed as follows:

under constraints

$$
\sum_{i=1}^{15} c_{i}^{1} x_{i}^{1}+c_{i}^{2} x_{i}^{2} \rightarrow \min
$$

$$
\begin{gathered}
x_{i}^{1} \geq Q_{i}^{1}, \quad i=1, \ldots, 15 \\
x_{i}^{2} \geq Q_{i}^{2}, \quad i=1, \ldots, 15 \\
\frac{x_{i}^{1}}{P_{i}^{1}} \leq T_{i}^{1}, \quad i=1, \ldots, 15 \\
\frac{x_{i}^{2}}{P_{i}^{2}} \leq T_{i}^{2}, \quad i=1, \ldots, 15 \\
x_{i}^{1}, x_{i}^{2} \geq 0, \quad i=1, \ldots, 15
\end{gathered}
$$

In the future, we will calculate the optimal values of mining operations. Work on the extraction and transportation of coal to warehouses is carried out on 4 sections. Enter the following notation: $x_{i}$ - amount of work on coal mining in section $i ; c_{i}-$ cost of performing mining operations on section $i ; Q_{i}$ - planned monthly volume of mining operations in section $i ; P_{i}$ - daily productivity of excavators in section $i ; T_{i}$ - the maximum allowed operating time of the excavator on section $i$.

The target function is expressed as follows:

under constraints

$$
\sum_{i=1}^{4} c_{i} x_{i} \rightarrow \min
$$

$$
\begin{gathered}
x_{i} \geq Q_{i}, \quad i=1, \ldots, 4 \\
\frac{x_{i}}{P_{i}} \leq T_{i}, \quad i=1, \ldots, 4 \\
x_{i} \geq 0, \quad i=1, \ldots, 4
\end{gathered}
$$

\section{Results and discussion}

Using mathematical statements of problems for the 1 st and 2nd levels of coal mine production process control, we will consider their practical implementation. 
For the main processes of level 1, technical and economic parameters of mining transport and other equipment of the coal mine are used, which are presented in table 1.The results of solving the problem of level 1 (expressions 1-4) are presented in table 2.

Table 1. Parameters for solving the problem of managing the production processes of a coal mine at level 1 .

\begin{tabular}{|l|c|c|c|c|}
\hline \multicolumn{1}{|c|}{$\begin{array}{c}\text { Name of the } \\
\text { process }\end{array}$} & $\begin{array}{c}\text { Planned } \\
\text { monthly } \\
\text { scope of work } \\
Q_{i}, \text { tons }\end{array}$ & $\begin{array}{c}\text { Daily equipment } \\
\text { performance } P_{i}, \\
\text { tons / day }\end{array}$ & $\begin{array}{c}\text { Maximum } \\
\text { allowed } \\
\text { operating time } \\
T_{i}, \text { days }\end{array}$ & $\begin{array}{c}\text { Average cost } \\
\text { of work } \\
\text { performed } c_{i}, \\
\text { rubles / ton }\end{array}$ \\
\hline $\begin{array}{l}\text { Drilling and } \\
\text { blasting }\end{array}$ & 1600000 & 71110 & 25 & 7.20 \\
\hline $\begin{array}{l}\text { Stripping } \\
\text { operations }\end{array}$ & 2700000 & 120000 & 25 & 30.69 \\
\hline Coal mining & 450000 & 20000 & 25 & 56.24 \\
\hline $\begin{array}{l}\text { Enrichment at } \\
\text { the factory }\end{array}$ & 460000 & 20444 & 25 & 38.34 \\
\hline Shipment & 414000 & 18400 & 22 & 8.40 \\
\hline
\end{tabular}

Table 2. Optimal volumes of work for the main processes of the coal mine.

\begin{tabular}{|l|c|c|}
\hline \multicolumn{1}{|c|}{ Name of the process } & $\begin{array}{c}\text { Optimal monthly } \\
\text { amount of work } \\
x_{i}, \text { tons }\end{array}$ & $\begin{array}{c}\text { Cost of performing } \\
\text { work, rubles }\end{array}$ \\
\hline Drilling and blasting & 1742195 & 12543804 \\
\hline Stripping operations & 2940000 & 90228600 \\
\hline Coal mining & 490000 & 27557600 \\
\hline Enrichment at the factory & 500878 & 19203663 \\
\hline Shipment & 450800 & 3786720 \\
\hline Total & 6123873 & 153320387 \\
\hline
\end{tabular}

When solving the tasks of level 2 of production process management, it is necessary not to exceed the average cost of performing work on each level 1 process at a given production rate. As noted above, drilling and blasting and stripping operations are carried out at 15 areas per month. The work involves drilling machines, auxiliary equipment, excavator-automobile complexes, technical and economic parameters of which are presented in table 3. At areas 1-5 and 15, excavators with a bucket capacity of $12 \mathrm{~m} 3$ are working together with BelAZ-75131 dump trucks with a load capacity of 130 tons; at areas 6,12 , and 14 operate excavators with a bucket capacity of $27 \mathrm{~m} 3$ in conjunction with the dump trucks BelAZ-75306 with payload capacity of 220 tonnes; at areas 7, 9, 10 and 13 operate excavators with a bucket capacity of $28 \mathrm{~m} 3$ in conjunction with the dump trucks BelAZ-75310 carrying capacity of 240 tons; at areas 8 and 11 operate excavators with a bucket capacity of $33 \mathrm{~m} 3$, in conjunction with the dump trucks BelAZ-75601 with load capacity of 360 tons. The results of solving the problem of determining the optimal volume of drilling and blasting and stripping operations for a month by sections (expressions 5-10) are presented in table 4 . 
Table 3. Parameters for solving the problem of managing drilling, blasting and stripping operations of a coal mine at level 2.

\begin{tabular}{|c|c|c|c|c|c|c|c|c|}
\hline $\begin{array}{c}\text { Section } \\
\text { number }\end{array}$ & $\begin{array}{c}Q_{i}^{1}, \\
\text { tons }\end{array}$ & $\begin{array}{c}Q_{i}^{2}, \\
\text { tons }\end{array}$ & $\begin{array}{c}P_{i}^{1}, \\
\text { tons/ } \\
\text { day }\end{array}$ & $\begin{array}{c}P_{i}^{2}, \\
\text { tons/ } \\
\text { day }\end{array}$ & $\begin{array}{c}T_{i}^{1}, \\
\text { days }\end{array}$ & $\begin{array}{c}T_{i}^{2}, \\
\text { days }\end{array}$ & $\begin{array}{c}c_{i}^{1}, \\
\text { rubles } \\
/ \text { ton }\end{array}$ & $\begin{array}{c}c_{i}^{2}, \\
\text { rubles } \\
/ \text { ton }\end{array}$ \\
\hline 1 & 18000 & 58000 & 36480 & 23375 & 25 & 25 & 7.2 & 49.07 \\
\hline 2 & 50000 & 80000 & 33600 & 23375 & 25 & 25 & 7.2 & 49.07 \\
\hline 3 & 64000 & 105000 & 25920 & 23375 & 25 & 25 & 7.2 & 49.07 \\
\hline 4 & 81000 & 151000 & 32640 & 23375 & 25 & 25 & 7.2 & 49.07 \\
\hline 5 & 93000 & 198000 & 37440 & 23375 & 22 & 22 & 7.2 & 49.07 \\
\hline 6 & 100000 & 213000 & 40320 & 85420 & 25 & 25 & 7.2 & 28.22 \\
\hline 7 & 120000 & 240000 & 34560 & 68685 & 25 & 25 & 7.2 & 25.98 \\
\hline 8 & 151000 & 253000 & 33600 & 101330 & 25 & 25 & 7.2 & 17.73 \\
\hline 9 & 179000 & 240000 & 32640 & 68685 & 25 & 25 & 7.2 & 25.98 \\
\hline 10 & 205000 & 309000 & 37440 & 68685 & 22 & 22 & 7.2 & 25.98 \\
\hline 11 & 221000 & 253000 & 40320 & 101330 & 25 & 25 & 7.2 & 17.73 \\
\hline 12 & 120000 & 213000 & 34560 & 85420 & 25 & 25 & 7.2 & 28.22 \\
\hline 13 & 117000 & 171000 & 33600 & 68685 & 25 & 25 & 7.2 & 25.98 \\
\hline 14 & 54000 & 128000 & 36480 & 85420 & 25 & 25 & 7.2 & 28.22 \\
\hline 15 & 16000 & 81000 & 33600 & 23375 & 25 & 25 & 7.2 & 49.07 \\
\hline
\end{tabular}

Table 4 presents results for two variants - the initial consolidation of equipment at the end of last month under the new consolidation of mining equipment in the analysis of the sections activities within a month and the timely adjustment of quantities on sites taking into account the average cost of works used in task 1 management level.

Results analysis of the solution shows that the decrease of the intensity of excavation and transportation of overburden on the 7th and 8th sections (240397 tons for the first option against 171712 tons for the second option on the 7 section and 253325 tons against 151995 tons for the 8 section) to partially compensate for the lag in the rate of stripping works by section 11 (253325 tons against 354655 tons), as well as increasing the pace of drilling and blasting operations at sections 7, 8 and 9 (respectively 120960 tons against 155520 tons; 151200 tons against 184800 tons; 179520 tons against 212160 tons), thus preparing the rock masses for further processing by excavators in the following months of work. In this case, the total cost of stripping work for the month for the first option from table 4 will be $94416048-1598880 * 7.2=82904112$ rubles. Hence, the average cost per 1 ton will be $82904112 / 2701340=30.69$ rubles/ton, which corresponds to the average cost of performing stripping operations for the month from table 1. If the volume of work is reallocated (the second version of table 4), the total cost of stripping work for the month will be $93357085-1699680 * 7.2=81119389$ rubles. Hence, the average cost per 1 ton will be $811193892632655=30.81$ rubles $/$ ton, which is almost the same as the average cost of performing stripping operations for the month from table 1 . Therefore, it can be considered that the second option of drilling and blasting and stripping operations at the sites for a month can be accepted as an alternative plan for carrying out work at the coal mine. 
Table 4. Optimal volumes of drilling and blasting and stripping operations of a coal mine.

\begin{tabular}{|c|c|c|c|c|c|c|}
\hline & \multicolumn{2}{|c|}{$\begin{array}{c}\text { At the initial fixing of mining and } \\
\text { transport equipment by sections (the } \\
\text { first option) }\end{array}$} & \multicolumn{2}{|c|}{$\begin{array}{c}\text { With the new fixing of mining } \\
\text { transport equipment by sections (the } \\
\text { second option) }\end{array}$} \\
\hline $\begin{array}{c}\text { Section } \\
\text { number }\end{array}$ & $x_{i}^{1}$, tons & $x_{i}^{2}$, tons & $\begin{array}{c}\text { The total cost } \\
\text { of performing } \\
\text { the work, in } \\
\text { rubles }\end{array}$ & $x_{i}^{1}$, tons & $x_{i}^{2}$, tons & $\begin{array}{c}\text { The total cost } \\
\text { of performing } \\
\text { the work, in } \\
\text { rubles }\end{array}$ \\
\hline 1 & 18240 & 58437 & 2998771 & 18240 & 58437 & 2998771 \\
\hline 2 & 50400 & 81812 & 4377310 & 50400 & 81812 & 4377310 \\
\hline 3 & 64800 & 105187 & 5627977 & 64800 & 105187 & 5627977 \\
\hline 4 & 81600 & 151937 & 8042911 & 81600 & 151937 & 8042911 \\
\hline 5 & 93600 & 198687 & 10423285 & 93600 & 198687 & 10423285 \\
\hline 6 & 100800 & 213550 & 6753195 & 100800 & 213550 & 6753195 \\
\hline 7 & 120960 & 240397 & 5964007 & 155520 & 171712 & 5581538 \\
\hline 8 & 151200 & 253325 & 4224656 & 184800 & 151995 & 4025831 \\
\hline 9 & 179520 & 240397 & 7893678 & 212160 & 240397 & 7774069 \\
\hline 10 & 205920 & 309082 & 9513864 & 205920 & 309082 & 9513864 \\
\hline 11 & 221760 & 253325 & 8243698 & 221760 & 354655 & 7885638 \\
\hline 12 & 120960 & 213550 & 6898347 & 120960 & 213550 & 6898347 \\
\hline 13 & 117600 & 171712 & 5308514 & 117600 & 171712 & 5308514 \\
\hline 14 & 54720 & 128130 & 4010445 & 54720 & 128130 & 4010445 \\
\hline 15 & 16800 & 81812 & 4135390 & 16800 & 81812 & 4135390 \\
\hline Total & 1598880 & 2701340 & 94416048 & 1699680 & 2632655 & 93357085 \\
\hline
\end{tabular}

When determining the optimal amount of work for mining sections (4 sections are used per month), the technical and economic parameters of excavator and automobile complexes are taken into account, as shown in table 5. At sections 1-4, respectively, operate excavators with a bucket capacity of $5 \mathrm{~m} 3$ together with the dump trucks BelAZ-7547 with payload capacity of 45 tons; excavators with a bucket capacity of $6.5 \mathrm{~m} 3$ in conjunction with the dump trucks BelAZ-7555 with capacity 55 tons; excavators with a bucket capacity of 12 $\mathrm{m} 3$, in conjunction with the dump trucks Hitachi EH 1700 lifting capacity 95 tons; excavators with a bucket capacity of $12.5 \mathrm{~m} 3$ together with BelAZ-75138 dump trucks with a load capacity of 120 tons. The results of solving the problem of determining the optimal volume of mining operations for a month by sections (expressions 11-14) are presented in table 6 . 
Table 5. Parameters for solving the problem of managing coal mine operations at level 2.

\begin{tabular}{|c|c|c|c|c|}
\hline $\begin{array}{c}\text { Section } \\
\text { number }\end{array}$ & $\begin{array}{c}\text { Planned monthly } \\
\text { volume of } \\
\text { mining } \\
\text { operations } \\
\text { tons }\end{array}$ & $\begin{array}{c}\text { Daily } \\
\text { productivity of } \\
\text { the excavator } \\
P_{i}, \text { tons / day }\end{array}$ & $\begin{array}{c}\text { Maximum } \\
\text { permissible } \\
\text { operating time of } \\
\text { the excavator } \\
T_{i}, \text { days }\end{array}$ & $\begin{array}{c}\text { Average cost of } \\
\text { mining operations } \\
c_{i}, \text { rubles / ton }\end{array}$ \\
\hline 1 & 35830 & 1592 & 25 & 116.13 \\
\hline 2 & 50620 & 2248 & 25 & 94.63 \\
\hline 3 & 66450 & 2952 & 25 & 54.56 \\
\hline 4 & 302040 & 13424 & 25 & 43.74 \\
\hline
\end{tabular}

Table 6. Optimal volumes of mining operations coal mine.

\begin{tabular}{|c|c|c|}
\hline Section number & $\begin{array}{c}\text { Optimal monthly } \\
\text { volume of mining } \\
\text { operations } x_{i}, \mathbf{T}\end{array}$ & $\begin{array}{c}\text { Cost of mining } \\
\text { operations, rubles }\end{array}$ \\
\hline 1 & 24676 & 2865644 \\
\hline 2 & 66316 & 6275709 \\
\hline 3 & 87084 & 4751612 \\
\hline 4 & 315464 & 13799821 \\
\hline Total & 493540 & 27692786 \\
\hline
\end{tabular}

At the same time, the average cost of 1 ton of coal per month from table 6 will be $27692786 / 493540=56.11$ rubles/ton, which is even slightly less than the average cost of performing mining operations per month from table 1 .

\section{Conclusion}

Using a two-level system for managing production processes at a coal mine allows you to flexibly coordinate actions between different departments, redistribute production resources to other areas, evaluate the interaction effectiveness of mining and transport equipment, its impact on the productivity of mining and stripping operations and, in general, on the cost of performing all processes at the coal mine at a given rate of production.

\section{References}

1. R. Kear, J. S. Afr. I. Min. Metall., 106, 93 (2006)

2. B. King, J. Min. Sci., 47(2), 247 (2011)

3. M. Osanloo, J. Gholamnejad, B. Karimi, Int. J. Min. Reclam. Env., 22(1), 2 (2008)

4. A. Tyurin, E3S Web of Conferences, 21, 01013 (2017)

5. A. Tyurin, A. Stoianov, E3S Web of Conferences, 105, 01038 (2019)

6. R.A. Carter, Eng. Min. J. 32, 28 (2012)

7. M. Munirathinam, J.C. Yingling, Int. J. Surf. Min. Reclamat. Environ., 8, 1 (1994) 
8. S. Alarie, M. Gamache, Int. J. Surf. Min. Reclamat. Environ., 16, 59 (2002)

9. C.H. Ta, J.V. Kresta, J.F. Forbes, H.J. Marquez, Int. J. Surf. Min. Reclamat. Environ., 19, $162(2005)$

10. A. Krause, C. Musingwini, J. S. Afr. Inst. Min. Metall., 107, 469 (2007)

11. C.N. Burt, L. Caccetta, Int. J. Surf. Min. Reclamat. Environ., 21, 263 (2007)

12. J. Krzyzanowska, J. S. Afr. Inst. Min. Metall., 107, 215 (2007)

13. S.V.bMkhatshwa, J. S. Afr. Inst. Min. Metall., 109, 223 (2009)

14. K.P. Chatterjee, J.D. Brake, CIM Bull. ,74, 103 (1981)

15. Y.C. Kim, M.A. Ibarra, Bulk Solids Handling, 1, 137 (1981)

16. J.H. Tu, V.J. Hucka, CIM Bull., 78, 53 (1985) 